\title{
To sleep overseas
}

\author{
Roxana Escobar Ñ̃̃̃ez
}

\begin{abstract}
In this piece, I reflect on my fears regarding the COVID-19 pandemic in Peru, the country with the third highest rate of deaths per capita cases in the world. As an international Peruvian student living in Canada, my mind and heart were constantly worrying about the safety of my family and friends in the months following the pandemic. In the last week of May, I realized that for the first time in my life, I could no longer remember my dreams. I was waking up at 4 am incessantly thinking about my country's situation. From the comfort of my Ph.D. desk, I saw how things were getting worse with time. Government efforts weren't succeeding. My family was calling every day with bad news. In June, the majority of my family was infected. I gave up on dreaming. I realized I did not have to dream anymore; the morning tales from Peru were surreal enough. This reflection is the outcome of a sleepless morning in the noisy construction site known as Toronto, Ontario.
\end{abstract}

\section{Keywords \\ COVID-19, Peru, dreams}




\section{To sleep overseas}

What do you dream about?

Since May, I wake up every night at 4 am with the same thought: I'm not dreaming anymore. I'm tired, and I'm concerned. I'm afraid, and every day I'm feeling more and more claustrophobic. As a Peruvian living in Canada, with all my family far away from me, it is easy to be afraid.

Especially when your country of residence does not care about you

and when your home country is in crumbles

I wonder.

How do you go to bed every night, when people in your beautiful city, thousands of them are walking for days or weeks to return to their places of origin? Because in Lima, there are no more jobs. There is no more food or hope. Hospitals are collapsing, and people are dying on the streets, some of COVID-19, some of hunger. La ciudad está llena de tristeza.

How do you close your eyes when the news shows people sleeping on the side of the road? Catching whatever is thrown at them from a moving car. Sometimes crackers, sometimes water, sometimes just words of encouragement. And while some are moving away from the darkness, others are disappearing in place. Two thousand women are missing - all of them during a national lockdown.

How do you have breakfast when all you see is that markets, such essential spaces for Peruvian people, filled with smells and sounds, full of colours and life, are now places of death. Everyone is infected with the damn virus. Market vendors, patrons, EVERYBODY. How do you wake up when all you can think is about the lady from the market, the one that is super nice every time you come back? A person who knows you since you were little. Is she safe? Would she be there the next time you visit? Ojalá que sí.

How do you eat calmly knowing that your brother went to the market yesterday? 
It is difficult to put clothes in the morning while reading a text saying: your cousins, your uncles, your aunties, ALL OF THEM, got infected on their way to work. Or when your mom calls you because her chest hurts. Or when your friend tells you that ten of your neighbours are dead. ALL GONE. And you are not there to say goodbye. My father is hurting. Acaba de perder a sus amigos.

How do you go back to sleep when your rent increases during a pandemic? And around you, constructions never stop. How do you write when you can't hear your thoughts? Or maybe you don't want to listen to them anymore? Is Toronto just noise?

I don't remember the last time I dreamt.

Do we even have mornings in a pandemic? 


\section{Author Biography}

Roxana Escobar Ñañez is a $\mathrm{PhD}$ student in Human Geography at the University of Toronto. Her research focuses on Afro-Latinx Black geographies, feminist geography, and fatphobia in Latin America. Her doctoral thesis analyses the different ways in which Afro-Peruvian women contribute to the history and spaces of the city of Lima. 